\title{
EVALUASI KINERJA BANGUNAN AKIBAT PENGARUH GEMPA RENCANA PADA STRUKTUR GEDUNG 3 LANTAI BERDASAR SNI 03-1726-2003
}

\author{
Ignatius Christiawan \\ Program Studi Diploma III Teknik Sipil \\ Fakultas Teknik Universitas Diponegoro
}

\begin{abstract}
Ignatius Christiawan, in this paper explain that In effort fulfill requirement the well building infrastructure, safety of building user such as building avalanche damage as result of earthquake is principal priority. Due to user safety to building avalanche as result of earthquake then it was issued the Procedure of Earthquake Endurance Planning SNI 03-1726-2003 that regulates of planning, build or operates a building. Problem emerge at the building which have the old regulation plan, so it was need evaluation based on the new regulation. Evaluation is conducted at the 3 floor laboratory and lecturing building. Research was focused on performance evaluation of structure on existing condition relate at regulation of the Procedure of Concrete Structure Calculation for the SNI 2847-2002, application for earthquake based on SNI-1726-2002. SAP 2000 is used to analyze the pushover to obtain the building ductility value and the reduction factor value $(R)$ from the building. The result of material test was obtained $f_{o}$ existing $17 \mathrm{Mpa}$ and $f_{y}$ existing $390 \mathrm{Mpa}$. The result of structure performance evaluation was obtained the service limit performance and the building unlimited performance fulfilling condition SNI - 1726-2002.
\end{abstract}

Keywords: plan earthquake, evaluation, safety.

\section{PENDAHULUAN}

Seiring dengan tuntutan manusia yang terus berkembang, maka dalam upaya memenuhi tuntutan tersebut diperlukan infrastruktur yang meliputi bangunan gedung, jalan, jembatan, bangunan air dan sarana umum lainnya. Infrastruktur yang baik dapat mempercepat pertumbuhan, dalam berbagai studi empirik yang pernah dilakukan diperlihatkan bahwa terdapat korelasi positip antara pertumbuhan di satu sisi dengan kualitas dan kuantitas infrastruktur di sisi yang lain. Dalam usaha memenuhi kebutuhan infrastruktur bangunan gedung yang baik keselamatan pengguna bangunan diantaranya terhadap pengaruh gempa merupakan prioritas utama.

Berkait dengan keselamatan pengguna bangunan terhadap gempa maka diterbitkan peraturan yang ketat dalam perencanaan, pembangunan maupun pengoperasian suatu bangunan gedung. Masalah yang muncul adalah pada bangunan yang sudah berdiri, karena perencanaan bangunan tersebut belum mencakup hingga evaluasi kinerja struktur gedung akibat pengaruh Gempa Rencana, karena masih menggunakan peraturan yang lama, sehingga diperlukan evaluasi berdasar peraturan yang baru (SNI 03-1726-2003)

Penelitian ini mempunyai tujuan sebagai berikut :

- Mengevaluasi kekuatan sisa struktur bangunan terutama kuat tekan beton $\mathrm{f}_{\mathrm{c}}$ ' pada kondisi existing.

- Melakukan Analisis Beban Statik Dorong (Pushover Analysis) untuk mendapatkan nilai daktilitas gedung dan nilai faktor reduksi $(R)$ yang sebenarnya dari gedung tersebut.

- Mengevaluasi kinerja batas layan dan kinerja batas ultimit struktur gedung akibat pengaruh Gempa Rencana.

Dengan dilakukannya penelitian ini diharapkan dapat memberikan masukan kepada pengelola gedung berkait dengan kinerja struktur gedung terhadap pengaruh gempa, sehingga dapat memperkecil resiko terjadinya korban jiwa akibat gempa yang kuat, membatasi kerusakan gedung akibat gempa ringan sampai sedang sehingga masih dapat diperbaiki serta membatasi ketidaknyamanan bagi penghuni ketika terjadi gempa ringan sampai sedang.

Untuk memberikan arah dalam melaksanakan penelitian agar tidak terjadi pengembangan permasalahan menjadi lebih komplek, maka dilakukan pembatasan sebagai berikut :

- Penelitian dilakukan pada gedung 3 lantai yang digunakan untuk laboratorium dan perkuliahan.

- Peraturan struktur beton mengacu pada Tata Cara Perhitungan Struktur Beton untuk Bangunan Gedung SNI-2847-2002, serta penerapan beban gempa berdasarkan ketentuan Tata Cara Perencanaan Ketahanan Gempa untuk Bangunan Gedung SNI 03-1726-2003.

- Program analisis struktur SAP 2000 digunakan untuk melakukan Analisis Beban Statik Dorong (Pushover Analysis) dengan masukan data hasil uji bahan kondisi existing. Penelitian difokuskan pada evaluasi kinerja batas layan dan kinerja batas ultimit struktur gedung. 
Semua bangunan sipil (gedung, jembatan, bangunan air) harus dirancang sesuai dengan fungsinya dengan mengindahkan persyaratan kekuatan, kekakuan, kestabilan, daktilitas dan ketahanan terhadap kondisi lingkungan. Namun setelah bangunan berdiri dapat terjadi kerusakan yang mengakibatkan persyaratan tersebut tidak terpenuhi lagi. Kerusakan dapat terjadi sejak bangunan dibuat maupun setelah beroperasi. Secara langsung maupun tidak, kerusakan akan menyebabkan degradasi kekuatan yang mengurangi kinerja struktur secara keseluruhan bahkan dapat mengancam keselamatan pengguna bangunan.(Triwiyono, 2003).

Kerusakan struktur beton pasca konstruksi dapat terjadi baik pada saat konstruksi maupun saat operasional bangunan. Kerusakan pada proses konstruksi akan memicu terjadinya kerusakan pada saat operasional. Kerusakan dapat disebabkan antara lain :

- Kesalahan Perencanaan

- Kesalahan Pelaksanaan

- Kesalahan Penggunaan (perubahan/ penambahan beban)

- Karena Pengaruh Eksternal/Lingkungan/Alam

SNI-2847-2002 telah mengatur mengenai tata cara evaluasi kekuatan struktur yang telah berdiri. Dalam peraturan tersebut dijelaskan tentang cara penentuan dimensi struktur, pengambilan sampel dan pengujian bahan serta perhitungan kuat tekan beton. Bila pengaruh defisiensi kekuatan struktur, dimensi struktur serta sifat bahan dapat diketahui, maka evaluasi kekuatan struktur secara analisis dianggap sudah memadai. Namun bila pengaruh defisiensi kekuatan struktur tidak diketahui dengan baik atau bila dimensi struktur serta sifat bahan yang dibutuhkan untuk tujuan analisis tidak memungkinkan diukur nilainya, maka harus dilaksanakan uji beban.

\section{LANDASAN TEORI}

Evaluasi Kekuatan Struktur Bangunan Existing

Tata Cara Perhitungan Struktur Beton untuk Bangunan Gedung SNI-03-2847-2002 mengatur mengenai evaluasi kekuatan struktur yang telah berdiri sebagai berikut :

- Bila timbul suatu keraguan mengenai keamanan dari suatu struktur atau komponen struktur pejabat bangunan yang berwenang boleh meminta suatu penilaian terhadap kekuatan struktur dengan cara analitis ataupun dengan uji beban, atau dengan kombinasi analisis dan uji beban.

- Bila pengaruh defisiensi kekuatan struktur diketahui dengan baik dan bila dimensi struktur serta sifat bahan yang dibutuhkan untuk tujuan analisis dapat diukur nilainya, maka evaluasi kekuatan struktur secara analitis berdasar data hasil pengukuran tersebut dianggap sudah memadai.
- Bila pengaruh defisiensi kekuatan struktur tidak diketahui dengan baik atau bila dimensi struktur serta sifat bahan yang dibutuhkan untuk tujuan analisis tidak memungkinkan untuk diukur nilainya, maka uji beban harus dilakukan bila struktur tersebut diinginkan untuk tetap berfungsi.

- Bila keraguan terhadap keamanan struktur atau bagian struktur adalah terkait dengan penurunan kinerja struktur sebagai fungsi waktu, dan bila respon struktur selama uji beban ternyata masih memenuhi kriteria penerimaan, maka struktur atau bagian dari struktur tersebut boleh tetap digunakan untuk jangka waktu tertentu. Pemeriksaan secara berkala harus dilakukan jika dianggap perlu oleh konsultan penilai.

\section{Analitis Beban Statik Dorong (Pushover Analysis)}

Analisis beban statik dorong (pushover analysis) adalah suatu analisis statik non linier dimana pengaruh Gempa Rencana terhadap struktur bangunan gedung dianggap sebagai beban-beban statik yang menangkap pada pusat massa masingmasing lantai, yang nilainya ditingkatkan secara berangsur-angsur sampai melampaui pembebanan yang menyebabkan terjadinya pelelehan (sendi plastis) pertama di dalam struktur bangunan gedung, kemudian dengan peningkatan beban lebih lanjut mengalami perubahan bentuk pasca-elastis yang besar sampai mencapai kondisi plastis (Pranata Y, 2006)

Analisis pushover dilakukan setelah analisis statis dan dinamis terlebih dahulu, analisis pushover ini dilakukan guna mengetahui sifat karakteristik gedung yang sebenarnya, berupa nilai daktilitas $(\mu)$ aktual dan faktor reduksi gempa $(R)$ aktual struktur, yang untuk selanjutnya akan digunakan dalam analisis dinamik lebih lanjut. Pada analisis ini dimasukkan tambahan data berupa lokasi atau letak sendi-sendi plastis yang diperkirakan akan terjadi, yaitu pada ujung-ujung balok induk dan pada kolom lantai dasar.

Tahapan analisis beban statik dorong sebagai berikut :

- Menentukan tipe dan besar beban yang terdiri dari dua macam beban yaitu : beban pertama berupa pembebanan beban mati dan beban hidup (gravitasi) pada struktur seperti biasa dengan awal kondisi pembebanan saat struktur masih dalam keadaan elastis (belum terbebani). Sedangkan beban kedua berupa pembebanan arah lateral, dengan awal kondisi pembebanan dimulai pada kondisi akhir pembebanan gravitasi sebelumnya.

- Meningkatkan beban lateral ini secara berangsur-angsur sehingga akan terbentuk sendi-sendi plastis pada lokasi-lokasi yang 
telah ditetapkan sebelumnya secara bertahap, sampai pada akhirnya struktur mencapai keruntuhan.

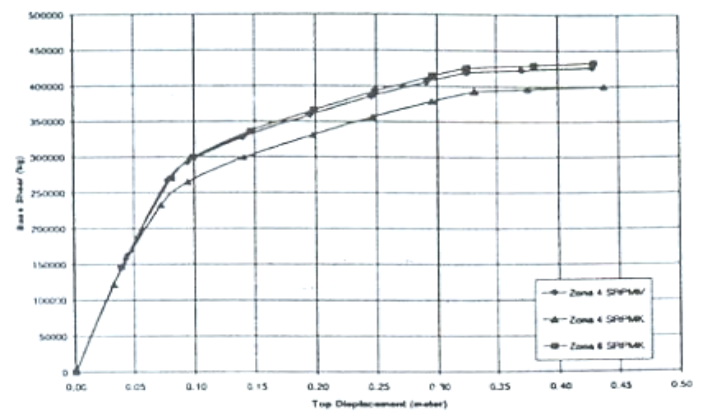

Gambar 1. Kurva kapasitas

Dari analisis ini didapatkan kurva kapasitas yang menunjukkan hubungan gaya geser dasar terhadap peralihan, yang memperlihatkan perubahan perilaku struktur dari linier menjadi nonlinier, berupa penurunan kekakuan yang diindikasikan dengan penurunan kemiringan kurva akibat terbentuknya sendi plastis pada kolom dan balok. Analisis beban statik dorong ini dilakukan secara terpisah untuk masing-masing arah sumbu lemah dan sumbu kuat gedung.

Dari nilai-nilai reduksi gempa yang telah diketahui untuk masing-masing arah, selanjutnya dicari nilai faktor reduksi gempa representatif $(R)$ yang berupa gabungan kedua nilai reduksi gempa untuk masing-masing arah, seperti pada persamaan 1 berikut :

$$
R=\frac{V_{x}^{0}+V_{y}^{0}}{\frac{V_{x}^{0}}{R_{x}}+\frac{V_{y}^{0}}{R_{y}}}
$$

\section{Evaluasi Kinerja Struktur Gedung}

Kinerja Batas Layan (pasal 8.1.1 SNI 03-17262002).

Kinerja batas layan struktur gedung ditentukan oleh simpangan antar-tingkat akibat pengaruh Gempa Rencana, untuk membatasi terjadinya pelelehan baja dan peretakan beton yang berlebihan, disamping untuk mencegah kerusakan non-struktur dan ketidaknyamanan penghuni. Simpangan antar-tingkat ini harus dihitung dari simpangan struktur gedung tersebut akibat pengaruh Gempa Nominal yang telah dibagi faktor skala.

Untuk memenuhi persyaratan kinerja batas layan struktur gedung, dalam segala hal simpangan antar-tingkat yang dihitung dari simpangan struktur gedung tidak boleh melampaui $0,03 / \mathrm{R}$ kali tinggi tingkat yang bersangkutan atau $30 \mathrm{~mm}$, bergantung yang mana yang nilainya kecil.
Kinerja Batas Ultimit (pasal 8.2.1 SNI 03-17262002).

Kinerja batas ultimit struktur gedung ditentukan oleh simpangan dan simpangan antartingkat maksimum struktur gedung akibat pengaruh Gempa Rencana dalam kondisi struktur gedung di ambang keruntuhan, untuk membatasi kemungkinan terjadinya keruntuhan struktur gedung yang dapat menimbulkan korban jiwa manusia dan untuk mencegah benturan berbahaya antar-gedung atau antar bagian struktur gedung yang dipisah dengan sela pemisah (sela dilatasi). Sesuai pasal 4.3.3 simpangan dan simpangan antartingkat ini harus dihitung dari simpangan struktur gedung akibat pembebanan gempa nominal, dikalikan dengan suatu faktor pengali $\zeta$ sebagai berikut :

- Untuk struktur gedung beraturan :

$$
\zeta=0,7 R
$$

- Untuk struktur gedung tidak beraturan

$$
\zeta=\frac{0,7 R}{\text { FaktorSkala }}
$$

dimana $\mathrm{R}$ adalah faktor reduksi gempa struktur gedung tersebut dan Faktor Skala adalah :

$$
\text { FaktorSkala }=\frac{0,8 V_{1}}{V_{t}} \geq 1
$$

Untuk memenuhi persyaratan kinerja batas ultimit struktur gedung, dalam segala hal simpangan antar-tingkat yang dihitung dari simpangan struktur gedung, tidak boleh melampaui 0,02 kali tinggi tingkat yang bersangkutan.

Evaluasi Kekuatan Struktur Bangunan Existing dengan cara analitis berdasar pada SNI 03-24872002.

Dalam melakukan evaluasi kekuatan struktur dengan cara analitis dilakukan pengumpulan data. Data-data yang diperlukan adalah data dimensi komponen struktur serta kualitas bahan yang meliputi antara lain :

- Kuat tekan beton

Sebagai data masukkan dalam melakukan analisis struktur, maka perlu diketahui kualitas beton, terutama kuat tekannya. Untuk mengetahui kuat tekan beton dapat dilakukan uji non-distructive test (uji tidak merusak) dengan pengambilan sampel bor inti (core case), Schmidt Hammer Test, UPV (Ultrasonic Pulse Velocity) dan lain-lain.

- Baja Tulangan

Tegangan leleh baja tulangan ditentukan berdasar data mutu baja yang digunakan pada pelaksanaan pembangunan (as build drawing). 


\section{METODA PENELITIAN}

Obyek penelitian adalah gedung 3 lantai yang digunakan untuk perkuliahan dan laboratorium.

Dalam penelitian ini, alat yang digunakan meliputi Rebar Locator, Schmidt Rebound Hammer Test dan Ultrasonic Pulse Velocity (UPV) Test. Penelitian diawali dengan persiapan/setting alat di laboratorium dengan melakukan kalibrasi, untuk memastikan alat berfungsi dengan baik dan akurat. Pengambilan data dilakukan pada 5 titik kolom lantai 1 (1-C ; 2-C ; 0-B ; 0-C ; 1-E) , 2 titik kolom (2-C ; 2-A), 2 titik balok (1/A-C ; 1/C-E) serta 2 luasan pelat (BC-01; DE-12) pada lantai 2, serta masing-masing 1 titik kolom (3-A) dan balok (2/AC) lantai 3. Dari hasil uji kuat tekan yang didapat, dihitung nilai rerata dan deviasi standar dari seluruh hasil uji. Dalam Triwiyono (2005) dinyatakan bahwa penetapan nilai kuat tekan beton fc' yang digunakan untuk evaluasi kekuatan struktur tidak boleh diambil lebih besar dari nilai terkecil dari 2 nilai kuat tekan yang dihitung dengan persamaan (9) dan (10) berikut:

- Menurut pasal 7.6.5). (4) SNI 03-3403-199103 disyaratkan bahwa kuat tekan rata-rata dari tiga beton inti adalah minimal sama dengan 0,85 f'c atau jika diperhitungkan suatu kemungkinan (probability) rentang kuat tekan minimum, dihitung dengan :

$f^{\prime} c=\frac{f^{\prime} \text { c rerata } 3 \text { benda kuattknrendah }}{0,85}$

- Tidak ada satupun beton inti yang kuat tekannya kurang dari 0,75 f'c, sehingga nilai kuat tekan beton dihitung dengan :

$$
f^{\prime} c=\frac{f^{\prime} c \text { terendah }}{0,75}
$$

Data berupa as build drawing dan hasil uji bahan dengan beban baru mengacu pada SNI 031727-1989 untuk beban statik dan SNI-1726-2002 untuk beban dinamik (beban gempa response spectrum) dimodelkan dengan program analisis struktur SAP 2000 versi 10.0.7 (gambar 1). Analisis Beban Statik Dorong (Pushover Analysis) dilakukan untuk mendapatkan nilai daktilitas gedung dan nilai faktor reduksi $(R)$ gedung sebenarnya. Jika tidak terpenuhi maka perhitungan diulang kembali dengan memasukkan nilai $(R)$ hasil analisis beban statik dorong pada perhitungan beban dinamik. Evaluasi kinerja struktur gedung dengan meninjau kinerja batas layan dan kinerja batas ultimit mengacu pada pasal 8 SNI-1726-2002.

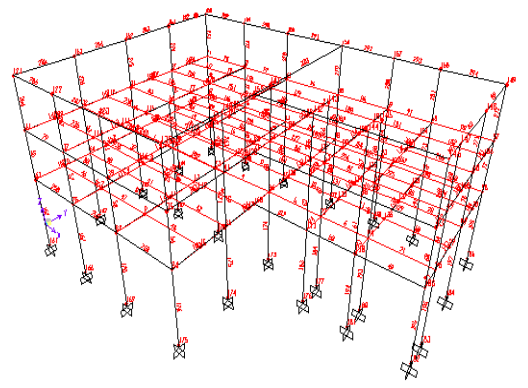

Gambar 2. Pemodelan Struktur gedung dengan 3 D

\section{HASIL DAN PEMBAHASAN \\ Pengolahan Data Lapangan}

Dari hasil uji bahan kondisi eksisting sesuai persamaan (5) dan (6) didapat kuat tekan beton $f c$, $=17 \mathrm{MPa}$ dan tegangan leleh baja tulangan berdasar as build drawing didapatkan fy $=390$ $\mathrm{MPa}$.

\section{Evaluasi Struktur \\ Analisis Pushover}

Gedung ini berada pada wilayah gempa 2 dibanguan diatas tanah lunak, hasil analisis pushover berupa grafik hubungan antara perpindahan (displacement, $\delta$ ) titik ujung atas kolom lantai 3 dengan gaya geser tingkat dasar (base shear, $V$ ), untuk masing-masing arah sumbu $\mathrm{x}$ dan sumbu y bangunan, didapat hasil seperti Gambar 3.
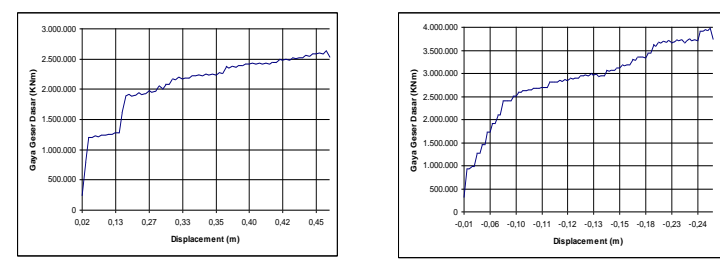

Gambar 3. Kurva hubungan $\delta$ - $V$ arah $\mathrm{X}$ dan

Dari grafik hubungan antara perpindahan (displacement, $\delta$ ) titik ujung atas kolom lantai 3 dengan gaya geser tingkat dasar (base shear, $V)$ tersebut didapatkan nilai daktilitas dan faktor reduksi gempa selengkapnya tercantum dalam Tabel 1.

Tabel 1.Rekapitulasi perhitungan nilai daktilitas dan reduksi gempa

\begin{tabular}{|c|c|c|c|c|c|c|}
\hline$\underset{\mathbf{h}}{\operatorname{Ara}}$ & $\begin{array}{c}\boldsymbol{\delta}_{\boldsymbol{y}} \\
(\mathbf{m})\end{array}$ & $\begin{array}{c}\delta_{m} \\
(\mathbf{m})\end{array}$ & $\boldsymbol{\mu}$ & $\boldsymbol{R}$ & $\begin{array}{c}\boldsymbol{R}_{m a} \\
k s\end{array}$ & $\begin{array}{c}R \\
\text { terpak } \\
a i\end{array}$ \\
\hline$X$ & $\begin{array}{c}0,07 \\
1\end{array}$ & $\begin{array}{c}0,46 \\
6\end{array}$ & $\begin{array}{c}6,25 \\
4\end{array}$ & $\begin{array}{c}10,4 \\
39\end{array}$ & 4,8 & 4,8 \\
\hline$Y$ & $\begin{array}{c}0,03 \\
1\end{array}$ & $\begin{array}{c}0,28 \\
3\end{array}$ & $\begin{array}{c}9,06 \\
6\end{array}$ & $\begin{array}{c}14,5 \\
06\end{array}$ & 4,8 & 4,8 \\
\hline
\end{tabular}


Dari nilai-nilai reduksi gempa yang telah diketahui untuk nilai $\mathrm{R}_{\mathrm{x}}=\mathrm{R}_{\mathrm{y}}=\mathrm{R}_{\text {maks }}$ dihasilkan nilai faktor reduksi gempa representatif sebesar $\mathrm{R}_{\text {maks }}$, sehingga nilai $\mathrm{R}$ yang akan dipakai untuk analisis struktur adalah $\mathbf{4 , 8}$.

\section{Evaluasi Kinerja Struktur Gedung}

.Hasil analisis struktur didapatkan pergeseran (displacement) untuk arah sumbu x dan y gedung tampak seperti tercantum dalam Tabel 2.

Tabel 2. Displacement arah X - Y pada gedung G

\begin{tabular}{ccc}
\hline \multirow{2}{*}{ Tingkat } & \multicolumn{2}{c}{ Displacement $(\mathbf{m m})$} \\
\cline { 2 - 3 } & sumbu X & Sumbu Y \\
\hline Tingkat I (+4.00) & 33,94 & 27,05 \\
Tingkat II (+8.00) & 45,65 & 37,57 \\
Tingkat III (+12.00) & 66,06 & 51,99 \\
\hline
\end{tabular}

\section{Kinerja Batas Layan}

Hasil analisis simpangan antar-tingkat tercantum dalam Tabel 3.

Tabel 3. Simpangan antar tingkat arah $\mathrm{X}$ dan $\mathrm{Y}$ pada gedung $\mathrm{G}$

\begin{tabular}{lccccc}
\hline \multirow{2}{*}{ Tingkat } & \multirow{2}{*}{$\begin{array}{c}\text { Tinggi } \\
(\mathbf{m})\end{array}$} & \multicolumn{2}{c}{$\begin{array}{c}\text { simpangan } \\
\text { terjadi }(\mathbf{m m})\end{array}$} & \multicolumn{2}{c}{$\begin{array}{c}\text { simpangan } \\
\text { ijin }(\mathbf{m m})\end{array}$} \\
\cline { 3 - 6 } Tingkat I & 5,9 & 33,94 & $\mathbf{X}$ & $\mathbf{X}$ & $\mathbf{Y}$ \\
Tingkat II & 4,0 & 11,72 & 10,52 & 25,87 & 36,87 \\
Tingkat III & 4,0 & 20,40 & 14,41 & 25,0 & 25,0 \\
\hline
\end{tabular}

Dari Tabel 3 tampak simpangan antartingkat yang terjadi pada semua tingkat dibawah simpangan ijin sehingga struktur gedung memenuhi standar kinerja batas layan sesuai ketentuan pasal 8.1.2 SNI-1726-2002.

\section{Kinerja Batas Ultimit}

Hasil analisis simpangan dan simpangan antar-tingkat maksimum dalam kondisi struktur gedung diambang keruntuhan tercantum dalam tabel 4 .

Dari Tabel 4 tampak simpangan dan simpangan antar-tingkat maksimum struktur gedung yang terjadi pada semua tingkat dibawah simpangan ijin sehingga struktur gedung memenuhi standar kinerja batas layan sesuai ketentuan pasal 8.2.2 SNI-1726-2002.

\section{KESIMPULAN}

Dari hasil pengujian dan analisis yang telah dilakukan pada penelitian ini maka dapat ditarik kesimpulan sebagai berikut :

- Hasil uji bahan kondisi eksisting didapat $f_{c}$ '= $17 \mathrm{MPa}$ dan $f_{y}=390 \mathrm{MPa}$.

- Hasil analisis beban statik dorong (Pushover analysis) didapatkan nilai faktor reduksi gempa representatif $(R)=4,8$.

- Evaluasi atas kinerja batas layan dan kinerja batas ultimit didapatkan simpangan

- antar tingkat < simpangan ijin, sehingga bangunan memenuhi ketentuan Tata Cara Perencanaan Ketahanan Ketahanan Gempa.

\section{DAFTAR PUSTAKA}

1. Badan Standarisasi Nasional, 2002, Tata Cara Perhitungan Struktur Beton untuk Bangunan Gedung, SNI-2487-2002, Jakarta

2. Badan Standarisasi Nasional, 1989, Tata Tata cara perencanaan pembebanan untuk rumah dan gedung, SNI 03-1727-1989, Jakarta

3. Iswari AY, 2004, Perkuatan Lentur Balok Tampang Persegi dengan Penambahan Tulangan Menggunakan Perekat Epoxy, Tesis S2

4. Nguyen,D.M.,Chan, T.K., dan Cheng, H.K., 2003, Effects of Plates Lenght on the Strength of Reinforced Concrete Beams Bonded with CFRP Plates, http//ww.must.edu.my/tkchan/nguyen1999a.pd f.

5. Pusat Penelitian dan Pengembangan Teknologi Pemukiman Departemen Pemukiman dan Presarana Wilayah, 2002, Standar Perencanaan Ketahanan Gempa Untuk Struktur Bangunan Gedung , SNI-17262002, Jakarta.

6. Triwiyono,A., 2006, Perbaikan dan Perkuatan Struktur Beton Pasca Gempa dengan $\boldsymbol{F R P}$, Himpunan Ahli Konstruksi Indonesia, Medan.

7. Wilson, L.E. and Habibullah, A., 1998, User Manual SAP 2000, Integrate Finite Element Analysis and Design of Structure, Analysis Reference, Computers and Structure Inc, Barkeley, California.

Tabel 4. Simpangan dan Simpangan antar tingkat maksimum arah X dan Y pada gedung G dengan $\mathrm{R}=4,8$

\begin{tabular}{|c|c|c|c|c|c|c|c|c|c|}
\hline \multirow[t]{2}{*}{ Tingkat } & \multirow{2}{*}{$\begin{array}{l}\text { Tinggi } \\
(\mathbf{m})\end{array}$} & \multicolumn{2}{|c|}{ FS } & \multicolumn{2}{|c|}{$\zeta$} & \multicolumn{2}{|c|}{$\begin{array}{c}\text { simpangan terjadi } \\
(\mathrm{mm})\end{array}$} & \multicolumn{2}{|c|}{$\begin{array}{c}\text { simpangan ijin } \\
(\mathrm{mm})\end{array}$} \\
\hline & & $\mathbf{X}$ & $\mathbf{Y}$ & $\mathbf{X}$ & $\mathbf{Y}$ & $\mathbf{X}$ & $\mathbf{Y}$ & $\mathbf{X}$ & $\mathbf{Y}$ \\
\hline Tingkat I & 5,9 & 2,62 & 3,44 & 1,28 & 0,98 & 43,54 & 26,43 & 118 & 118 \\
\hline Tingkat II & 4,0 & 2,62 & 3,44 & 1,28 & 0,98 & 15,03 & 10,28 & 80 & 80 \\
\hline Tingkat III & 4,0 & 2,62 & 3,44 & 1,28 & 0,98 & 26,18 & 14,08 & 80 & 80 \\
\hline
\end{tabular}

